\title{
Renin Levels in Nephroblastoma (Wilms' Tumour) Report of a Renin Secreting Tumour
}

\author{
J. D. MITCHELL, THELMA J. BAXTER, J. R. BLAIR-WEST, and D. A. MCCREDIE \\ From Royal Children's Hospital, Melbourne; Department of Pathology, University of Melbourne; \\ Howard Florey Laboratories, Department of Physiology, University of Melbourne; and \\ Department of Paediatrics, University of Melbourne, Victoria, Australia
}

Mitchell, J. D., Baxter, Thelma J., Blair-West, J. R., and McCredie, D. A. (1970). Archives of Disease in Childhood, 45, 376. Renin levels in nephroblastoma (Wilms' tumour). Report of a renin secreting tumour. The case history is reported of a child aged 1 year 10 months with malignant hypertension in association with Wilms' tumour. In addition there was a marked electrolyte disturbance, with hyponatraemia and hypokalaemia, and a blood picture of microangiopathic haemolytic anaemia. All these features resolved after removal of the kidney and tumour. Pre-operative plasma renin concentration was extremely high and had returned to normal 3 months after operation. The renal tumour showed a marked degree of differentiation, with glomerulus-like structures attached to tubules, and significant quantities of renin were found on assay. No renin was detected in the renal cortex of the affected kidney. In two other normotensive patients with Wilms' tumour no renin could be detected in the tumour tissue. We consider that the evidence suggests that this patient had a renin-secreting nephroblastoma.

The association of hypertension with Wilms' tumour was first reported by Pincoffs and Bradley (1937) who described 4 patients, in 2 of whom the hypertension remitted after operation, only to rise again with the recurrence of the tumour. The most severely affected of these patients had a welldifferentiated tumour containing both cystic and glomerulus-like structures. Extracts of this tumour were tested for pressor activity in dogs with negative results (Pincoffs and Bradley, 1937; Bradley and Pincoffs, 1938).

A mild to moderate increase of blood pressure is now well recognized in Wilms' tumour though its incidence appears to vary considerably in different series. Bradley and Drake (1949) described hypertension in 10 out of 12 patients. Campbell (1951), reviewing the literature, suggested an incidence of $75-90 \%$. On the other hand many comprehensive reviews do not mention the problem (Jagasia et al., 1964; Lalli et al., 1966; Parkkulainen, Sirola, and Sulamaa, 1965; Schweisguth and Bamberger, 1965), while Howard (1957) in a review of 26 cases states that the blood pressure was normal in all patients in whom it was measured.

Received 4 September 1969.
Though Lattimer, Melicow, and Uson (1958) $\stackrel{\unrhd}{\unrhd}$ found a moderate increase in blood pressure in $19 \overrightarrow{\overrightarrow{0}}$ out of 32 patients in whom it was recorded, the 3 highest diastolic reading was only $110 \mathrm{~mm}$. $\mathrm{Hg}$. Severe hypertension with retinal changes and encephalopathy is certainly an uncommon feature but has been described by Daniel (1939), Bradley and Drake (1949), Hughes, Rosenblum, and Horn (1949), Cox and Smellie (1955-56), and Gooding and Raslavicius (1965).

This report concerns an infant with Wilms' tumour and malignant hypertension. In view of a 욱 recent report of a possible renin-secreting tumour $D$ (Robertson et al., 1967), we decided to check the possibility that the hypertension was related to $N$ production of renin by the tumour in this patient. Renin levels were measured in plasma, kidney, and $\tilde{O}$ tumour, and compared with findings in two normotensive patients with nephroblastoma. Some of $\underset{Q}{ }$ these findings have been reported briefly elsewhere 0 (Blair-West, McCredie, and Mitchell, 1968b).

\section{Case Report}

A 23-month-old girl presented on 17 February 1968, because of failure to thrive. Her birthweight had been $3.38 \mathrm{~kg}$. after uncomplicated pregnancy, labour, 
and delivery. From the age of 12 months the child had shown poor appetite and weight loss associated with chronic constipation. Polydipsia and polyuria were noticed at about the same age. Her blood pressure was $110 / 70 \mathrm{~mm} . \mathrm{Hg}$ at 17 months, and one month later albuminuria (300 mg./100 ml.) was recorded. Microscopy of the urine at that time was normal. On presentation the patient was a thin, ill-looking child. She was afebrile and weighed $9 \mathrm{~kg}$. A large mass was palpable in the right side of the abdomen. Her blood pressure was $260 / 200 \mathrm{~mm}$. $\mathrm{Hg}$ and retinal exudates, haemorrhages, and moderate oedema of the optic disks were present (Fig. 1).

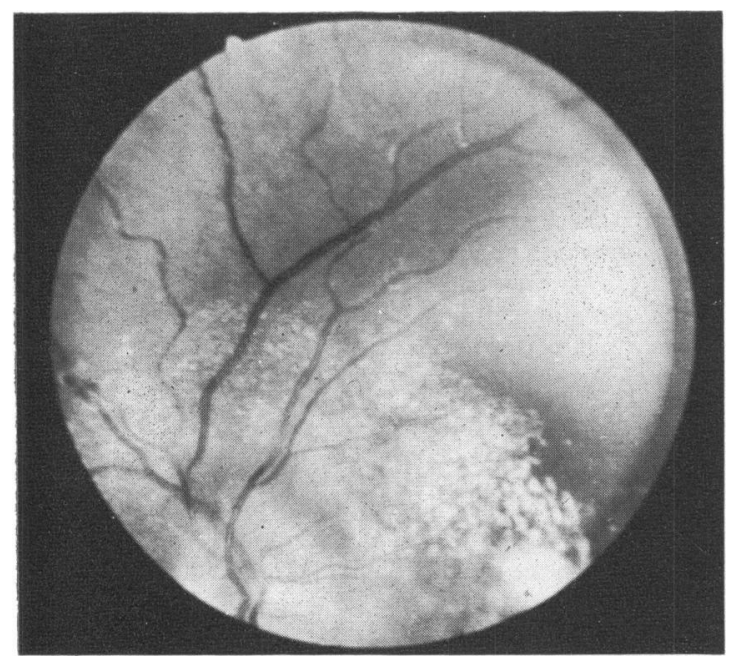

FIG. 1.-Photograph of optic fundus of patient showing retinal exudate and swelling of optic disk.
Initial investigations disclosed $\mathrm{Hb} 16.2$ g./100 ml.; leucocytes $20,600 / \mathrm{cu} . \mathrm{mm}$. (73\% polymorphs, $20 \%$ lymphocytes, $6 \%$ basophils, $1 \%$ monocytes); blood film and platelet count normal; blood urea $72 \mathrm{mg} . / 100 \mathrm{ml}$; serum electrolytes-sodium $126 \mathrm{mEq} / \mathrm{l}$., potassium $2 \cdot 8$ $\mathrm{mEq} / \mathrm{l}$., chloride $79 \mathrm{mEq} / \mathrm{l}$; blood $p \mathrm{H}$ was $7 \cdot 43$, $\mathrm{PCO}_{2} 41 \mathrm{~mm}$. $\mathrm{Hg}$; standard bicarbonate $26.0 \mathrm{mEq} / \mathrm{l}$., total $\mathrm{CO}_{2} 27 \cdot 6 \mathrm{mEq} / 1$, and base excess $+2 \cdot 7 \mathrm{mEq} / 1$. Urine showed moderate albuminuria and glycosuria but no cells or bacteria. $X$-ray of the chest indicated clear lung fields and the cardiac outline appeared normal in size. No abnormalities were detected in a skeletal survey.

A selective renal arteriogram on day 2 showed stretching of the main branches of the right renal artery around a large renal mass with some 'tumour circulation', confirming the diagnosis of Wilms' tumour. Some functioning renal tissue was present at the upper pole. The left renal system appeared normal (Fig. 2). An inferior vena cavogram showed a constant filling defect in the region of the renal veins.

Dactinomycin therapy was begun, and, the following day (day 3), blood was drawn for plasma renin, after which antihypertensive treatment with intramuscular pentolinium tartrate was started. Surgical removal was planned after three daily doses of dactinomycin, but was postponed because of severe haematological disorder and persisting electrolyte imbalance. Progress serum electrolytes, blood urea, diastolic blood pressure, $\mathrm{Hb}$, and platelet levels are shown in Fig. 3. Serum electrolytes tended to remain low despite vigorous intravenous replacement including hypertonic $(3 \%)$ saline. The blood pressure remained raised though, for the most part, diastolic blood pressure was close to $100 \mathrm{~mm}$. Hg.

By day $4, \mathrm{Hb}$ had fallen to $7 \cdot 3 \mathrm{~g} . / 100 \mathrm{ml}$. and platelets to $16,000 /$ cu.mm. Dactinomycin therapy was tem-

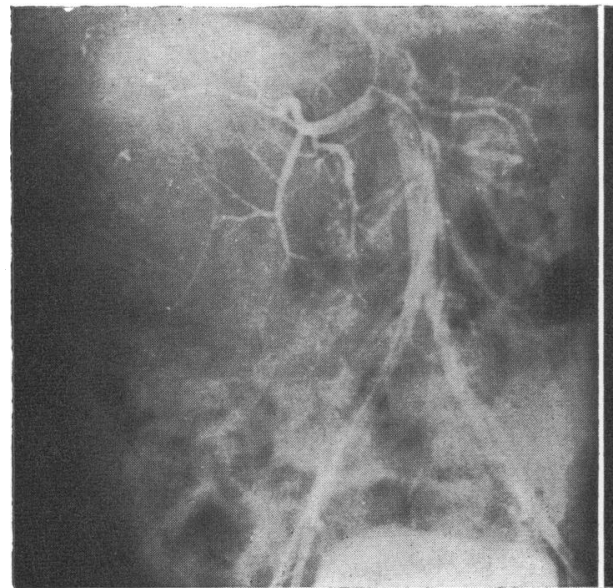

(a)

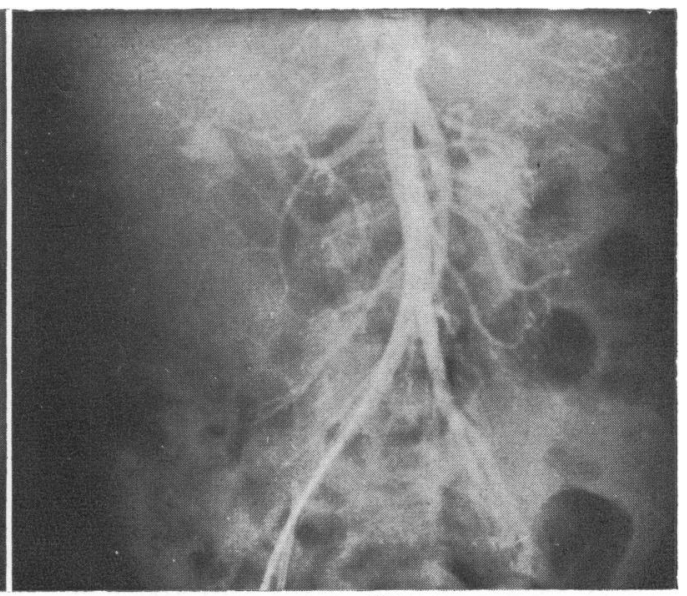

(b)

FIG. 2.-Selective renal arteriography. (a) Early phase with stretching of the main branches of the renal artery around a large mass. Note the areas of tumour circulation scattered through most of tumour. (b) Later phase with some excretion of dye from upper pole. 


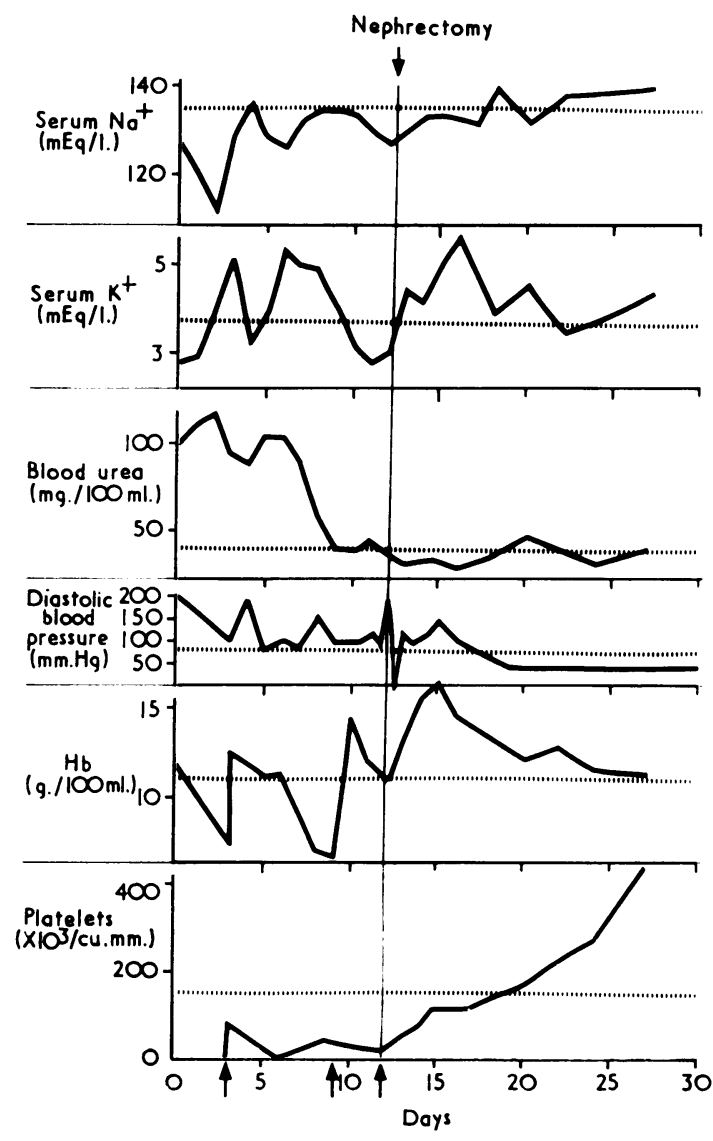

FIG. 3.-Clinical progress of the patient. Arrows on abscissa represent blood transfusion. Dactinomycin was given on days $2,3,4,10,12,14,16$, and 19 .

porarily discontinued, $400 \mu \mathrm{g}$. having then been given. The blood picture at that stage was that of a micro-angiopathic haemolytic anaemia with numerous burr cells, micro-spherocytes, and fragmented cells (Fig. 4). Fibrinogen index and prothrombin levels were normal. Acute renal insufficiency was indicated by a rising blood urea and reduced urine output, despite adequate hydration. Fresh blood was transfused producing a further rise in blood pressure to $300 / 260 \mathrm{~mm}$. $\mathrm{Hg}$ with the onset of a triple rhythm and some hepatic enlargement. The patient was then digitalized and intravenous frusemide given. This produced a rapid improvement in urinary output. By day 6 platelets had fallen to $3000 / \mathrm{cu} . \mathrm{mm}$. and hydrocortisone therapy was begun, together with ampicillin and methicillin. By day 10 her condition had improved: serum electrolytes were normal, blood urea had fallen to $40 \mathrm{mg} . / 100 \mathrm{ml}$., and platelets had risen to $42,000 / \mathrm{cu} . \mathrm{mm}$. Dactinomycin was again administered on the 10th and 12th days, and laparotomy was performed on the 14th day, after a further injection. of $140 \mathrm{\mu g}$. dactinomycin. In all 5 doses of dactino-을 mycin (totalling $670 \mathrm{\mu g}$.) were given over a period of 12 days before operation, together with a further $140 \stackrel{\text { ? }}{?}$ $\mu \mathrm{g}$. at the time of operation. Antihypertensive agents? were discontinued 12 hours before operation.

At operation a large encapsulated spheroidal mass was $\frac{\bar{c}}{\overrightarrow{5}}$ found occupying the outer part of the right kidney about its middle, and compressing the renal pelvis. Blood pressure rose to high levels during operation, but removal of the right kidney and tumour produced $\overrightarrow{0}$ an immediate fall in blood pressure which was unrecord- $-\overrightarrow{-}$ able for 45 minutes, despite noradrenaline infusion, but $\vec{\omega}$ which then rose to supranormal values, necessitating further antihypertensive treatment. The post-operativeo course was otherwise uneventful, the platelet count? rising to 78,000 within 48 hours, and the serum electro-cr lytes and blood urea remaining normal.

Deep $x$-ray therapy was given for 3 weeks after opera $-\stackrel{\oplus}{-}$ tion (1850 rads anteriorly and 1850 rads posteriorly to $w$ the tumour bed), and a further 2 injections of $140 \mu \mathrm{g}$. dactinomycin were given over the succeeding 6 days. 을 Methyldopa was continued for approximately 6 weeks after operation, and then discontinued without recur- $c$ rence of hypertension. 12 months later she appears a normal healthy child with blood pressure of $75 / 50 \mathrm{~mm}$. $\mathrm{Hg}$.

Pathological examination of kidney and tumour. The tumour was a spherical, encapsulated mass occupying the outer part of the kidney about its middle, and compressing the renal pelvis. It weighed approximately $160 \mathrm{~g}$. and measured $9 \times 7 \times 6 \mathrm{~cm}$. (Fig. 5). The $\frac{\mathrm{O}}{\Phi}$ renal vein was thin and free of tumour. There was $\varrho$ no marked distortion of the arterial pattern. On $\overrightarrow{\bar{O}}$ section the mass was yellowish tan in colour. Several 3 areas of haemorrhage and necrosis were apparent and $\vec{T}$ two fluid-filled cysts.

Histological examination showed considerable differentiation of the tumour, with numerous structures closely resembling glomeruli, including capsules, $\frac{?}{\sigma}$ 'Bowman's space', capillaries, and a vascular pedicle. $\overline{3}$ Irregular tubules appeared to be associated with these bodies and the whole was embedded in a moderately dense fibromuscular stroma (Fig. 6). The kidney showed marked tubular dilatation and atrophy, with 음 fibrosis and fibrinoid changes in some glomeruli (Fig. 7). There was some fibrinoid necrosis of afferent arterioles, 은 and larger vessels showed muscular hypertrophy. No juxtaglomerular cells were shown in either renal $\mathcal{N}$ tissue or tumour.

Microdissection of tumour (Fig. 8). The various $\omega$ parenchymal units dissected free from the tumour mass were heavily embedded in dense fibrocollagenouse connective tissue. These ranged from solid little $\Phi$ aggregations of cells, many of which were spherical in shape, to well-differentiated renal corpuscles with their $\square$ attached proximal tubules. The short lengths of $\vec{i}$ proximal tubules dissected free were brittle and rigid and $\vec{\Phi}$ therefore easily fractured. In addition, some renal 


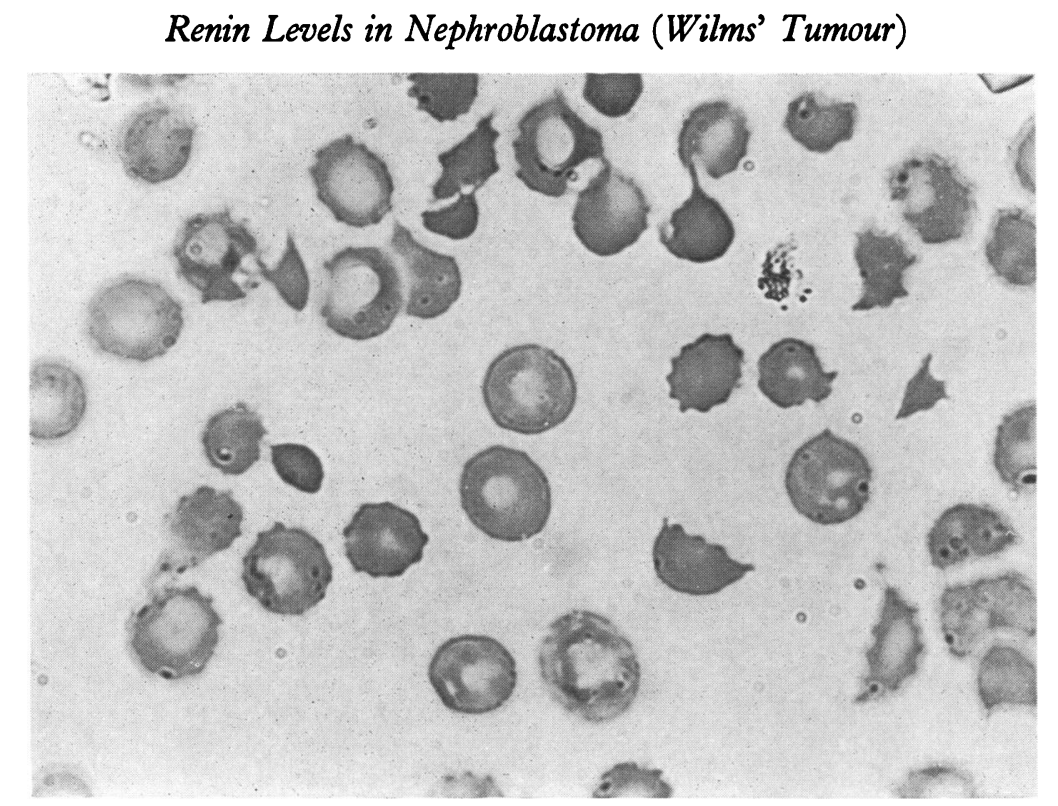

FIG. 4.-Blood film of patient, showing burr cells, poikilocytes and microspherocytes.

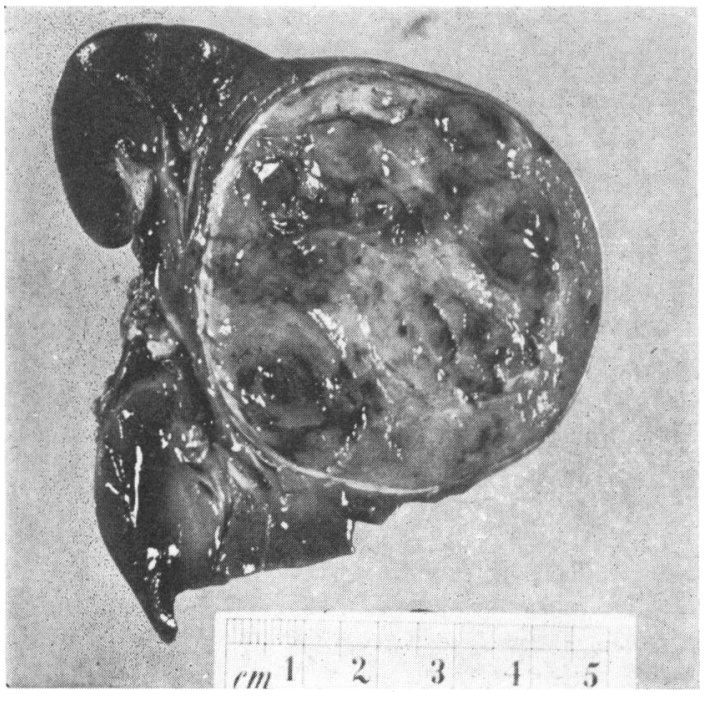

FIG. 5.-Operative specimen of kidney and tumour.

corpuscles were observed which were isolated structures, except for their attachment to vessels, while others were attached to small blindly-ending tubules; some were of cystic proportions.

Dissection of the kidney showed a marked range of variation; many of the nephrons were small atrophied units while others closely approached the normal. Most of the proximal convoluted tubules were tightly and rigidly coiled making manipulation difficult. Almost without exception the distal convoluted tubules were cystically dilated for most of their length. Most arterioles were thickened and Ludwig's vessel was frequently observed.

Renin assay. Plasma renin concentration (PRC) was measured by enzyme kinetic assay (Blair-West et al., 1967), similar to the method described by Skinner (1967). The normal range for this method is 10-35 ng./hr. per ml. (i.e. ng. angiotensin produced per hr. of incubation per $\mathrm{ml}$. plasma) for sodium replete adults after 12-16 hours' bedrest. The renin content of kidney cortex and tumour tissue was determined by the method previously described for sheep kidneys (Blair-West et al., 1967). At the present time no data are available for normal human kidneys by this method, though 11-238 Goldblatt units/g. cortex have been detected in the cortex of kidneys removed from adult patients with renal disease. Renin content is expressed in Goldblatt units/g. tissue by comparison with porcine (Nutritional Biochemicals Corporation) and ovine renin preparations. Because much work remains to be done to establish normal levels and appropriate units, the results in this report are interpreted on the basis of the presence or absence of renin in the tissues studied.

PRC was measured in this patient before starting antihypertensive therapy, but 20 hours after the first dose of dactinomycin. Serum $\mathrm{Na}+$ was then 111 $\mathrm{mEq} / \mathrm{l}$. A further blood sample was obtained three months after operation when the patient was clinically well, normotensive, and off all treatment. PRC was $430 \mathrm{ng} . / \mathrm{hr}$. per $\mathrm{ml}$. in the pre-operative sample and $23 \mathrm{ng}$./ $/ \mathrm{hr}$. per $\mathrm{ml}$. post-operatively. Specimens of the tumour and of the kidney were also assayed for renin content. No renin was detected in two samples of kidney cortex, but significant amounts $(2 \cdot 0$ and $3 \cdot 6$ 


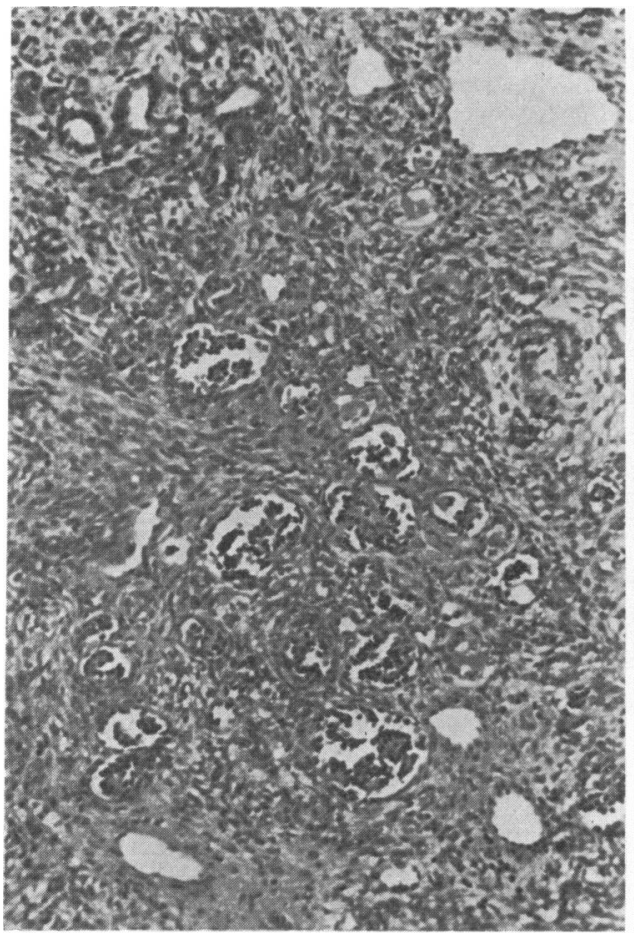

(a)

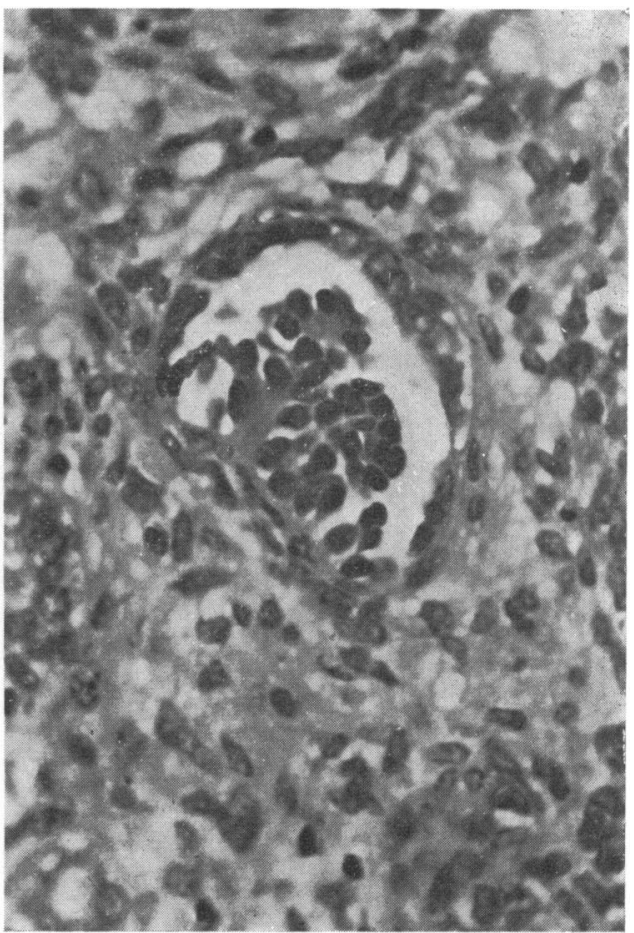

(b)

FIG. 6.-(a) Low-power view of section of tumour $(\times 65)$. (b) High-power view of glomerulus-like structure $(\times 260)$.

Goldblatt units/g. tissue) were found in two samples of the tumour.

At the same time two other patients with Wilms' tumour were investigated. Results together with those of our patient are shown in the Table. Neither of these two patients was hypertensive and the tumours showed no differentiation into glomeruloid structures. PRC of Case 1 was $80 \mathrm{ng}$./hr. per ml. This is above the normal adult range and similar to the increased levels found in normal subjects on a low sodium diet. Renin was undetectable in both tumours but detectable in small amounts in the renal cortex.

TABLE

Renin Levels in Patients with Wilms' Tumour

\begin{tabular}{|c|c|c|c|}
\hline & \multicolumn{3}{|c|}{ Renin Levels } \\
\hline & $\begin{array}{c}\text { Plasma } \\
\text { (ng. } / \mathrm{hr} . / \mathrm{ml} .)\end{array}$ & $\begin{array}{c}\text { Kidney } \\
\text { (U/g. cortex })\end{array}$ & $\underset{\text { (U/g.) }}{\text { Tumour }}$ \\
\hline $\begin{array}{l}\text { This patient } \\
\text { Pre-op. }\end{array}$ & 430 & $\begin{array}{c}<0 \cdot 3 \\
\text { (2 samples) }\end{array}$ & $\begin{array}{c}3 \\
\text { (mean of } 2 \\
\text { samples) }\end{array}$ \\
\hline $\begin{array}{l}3 \text { mth. after op. } \\
\text { Case } 1 \\
\text { Case } 2 \\
\text { Normal range } \\
\text { (adult) }\end{array}$ & $\begin{array}{r}23 \\
80 \\
10-40\end{array}$ & $\begin{array}{l}6.5 \\
0.5\end{array}$ & $\begin{array}{l}<0.3 \\
<0.3\end{array}$ \\
\hline
\end{tabular}

\section{Discussion}

Severe hypertension with encephalopathy and/or $\frac{\bar{\partial}}{3}$ retinal changes is an uncommon sequel of Wilms' tumour, but has been described by a number of authors. Possible origins of hypertension in this condition are renal arterial obstruction (Goldblatt et al., 1934), perirenal compression as in the cello- $\frac{0}{3}$ phane-wrap kidney (Page, 1939), or production of a humoral agent by the tumour itself. In each $\delta$ circumstance it seems likely that the reninangiotensin system is the cause of the high blood $\frac{}{5}$ pressure. However, recent clinical (Mulrow, $>$ Lytton, and Stansel, 1966; Brown et al., 1967; Meyer et al., 1967), and experimental (Gross, $\bar{N}$ Brunner, and Ziegler, 1965; Brown et al., o 1966; Blair-West et al., 1968a) studies have $\mathcal{N}$ failed to show consistently raised plasma levels of N renin or angiotensin in unilateral renovascular $\underset{2}{\sigma}$ hypertension. A more consistent increase has been 0 reported in malignant hypertension with severe $\mathbb{D}$

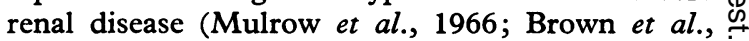
1964a; Massani et al., 1966).

If hypertension associated with Wilms' tumour is in fact due to a humoral factor released from the $\stackrel{\mathbb{D}}{\overparen{D}}$ kidney or tumour, it is likely that this factor is $\underset{\mathbb{Q}}{\mathbb{Q}}$ 


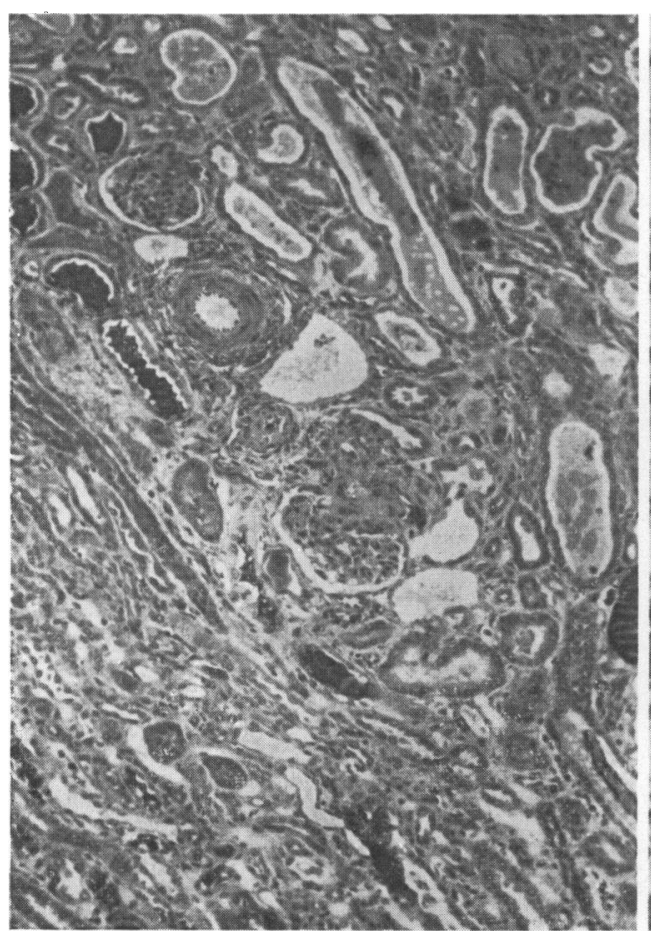

(a)

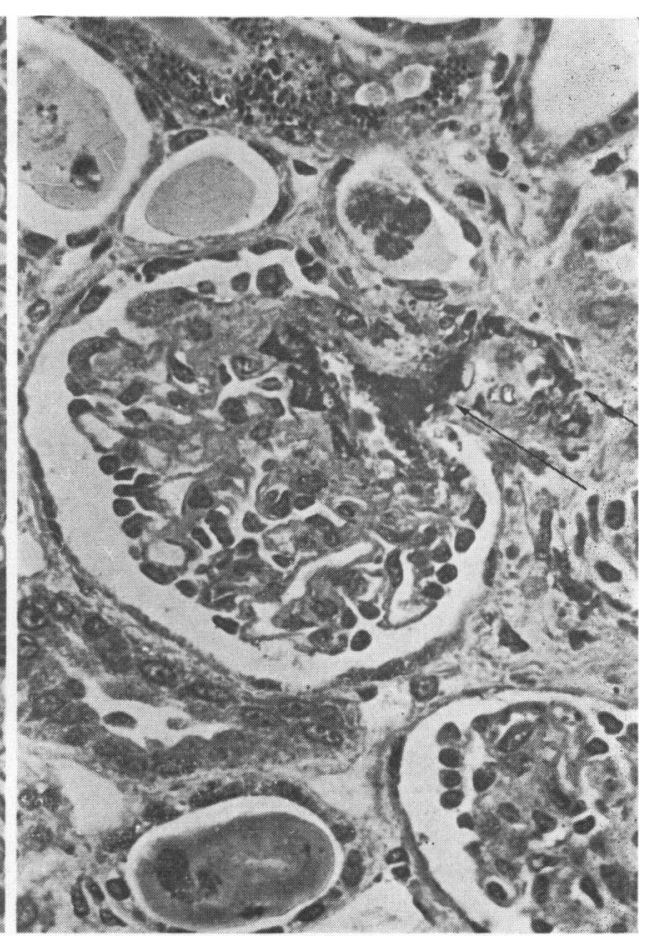

(b)

FIG. 7.-(a) Low-power view of kidney $(\times 65)$. (b) High-power view of glomerulus $(\times 260)$, stained with PTAH. Arrows point to fibrin deposits in wall of afferent arteriole and in glomerulus.

renin. The investigations in the three children included in this report are not sufficient to settle this point, but there are several pertinent findings.

(1) Only one child was hypertensive. This child had a very high plasma level of renin preoperatively and a renin-containing tumour.

(2) This child also had a severe electrolyte disturbance, such as may be seen with increased activity of the renin-angiotensin-aldosterone system (Bartter et al., 1962; Cannon et al., 1968).

(3) Hypertension was abolished by removal of the kidney and the tumour, and PRC was normal when measured 3 months after operation.

(4) The severity of the hypertension in association with the raised PRC is consistent with the relation reported in malignant hypertension.

(5) The pre-operative PRC was much greater than that seen after severe dietary sodium restriction, which approximately doubles PRC as measured by the present method.

(6) The histology of the kidney and tumour suggest that either or both might have produced high circulating renin levels. Renal histology, was that of a microangiopathic haemolytic anaemia, with fibrosis and fibrinoid changes in the glomeruli and some fibrinoid necrosis of the afferent arterioles. A similar picture has been reported in malignant hypertension (Brain, Dacie, and Hourihane, 1962), and also in association with Wilms' tumour (Denys et al., 1967). Both histology and microdissection of the tumour revealed a very advanced degree of differentiation, consistent with the possiblity of a renin-secreting tumour.

(7) Significant quantities of renin were seen in the tumour, but not in the kidney, of the hypertensive patient, while no renin was found in the tumours of two normotensive patients. The low level of renin shown in the kidney in all 3 patients may have resulted from pre-operative dactinomycin treatment, as dactinomycin, by virtue of its effect on messenger RNA protein synthesis, would be expected to decrease renin production.

A number of reports has suggested that the hypertension results from compression of the renal artery by the tumour (Daniel, 1939; Koons and 


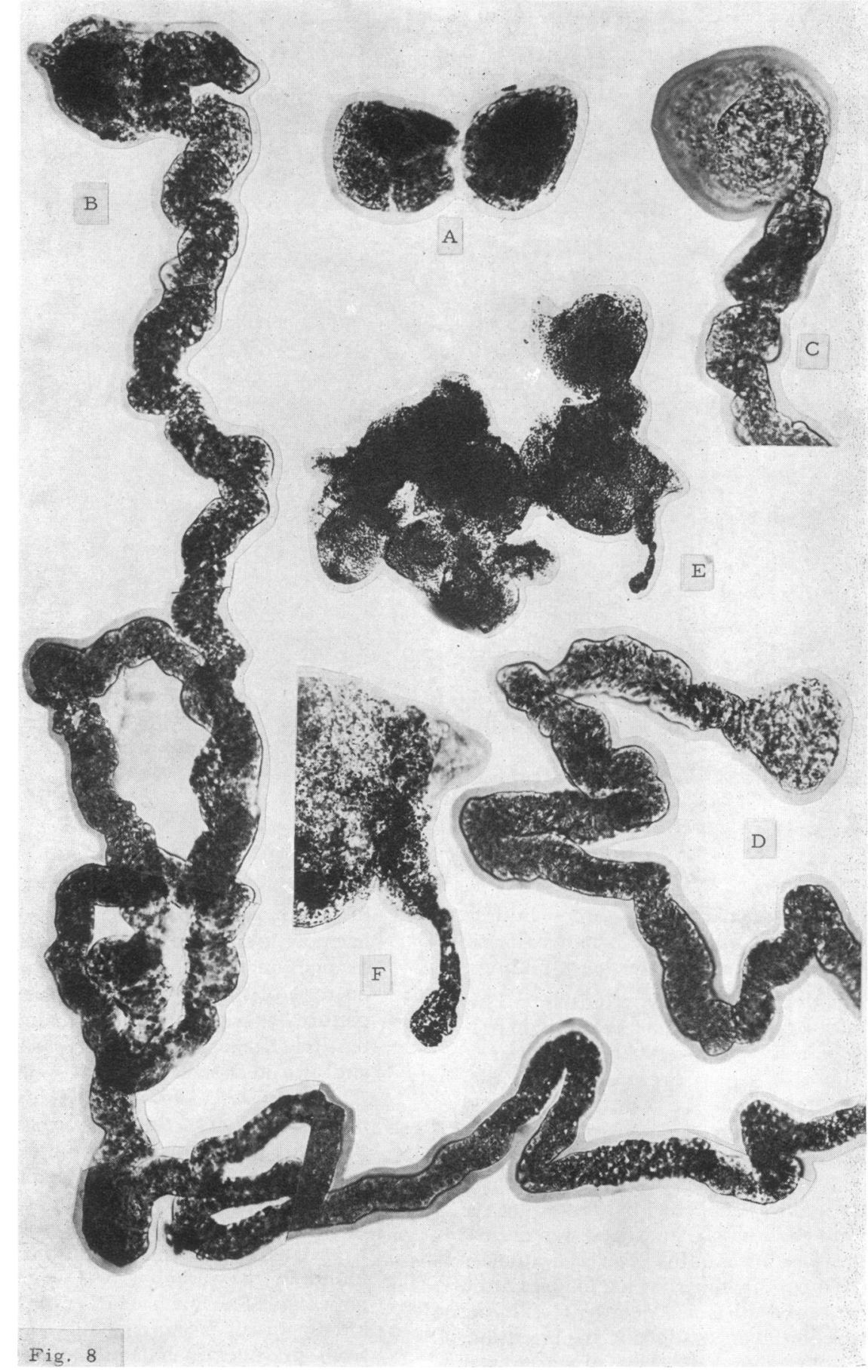

Fig. 8.-Microdissection of tumour. (A) Two solid aggregations of cells dissected free from dense interstitial tissue $(\times 120)$. (B) Montage: Proximal convoluted tubule with its attached renal corpuscle. This was the longest of the nephron components seen. It was rigidly coiled and was broken when manipulation was attempted

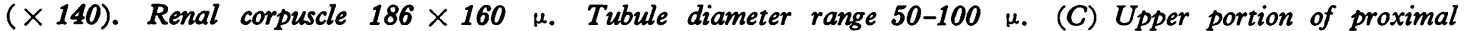
convoluted tubule attached to a large transparent renal corpuscle. Renal corpuscle $225 \times 211 \mu$. Tubule diameter range 74-87 $\mu$. (D) Upper portion of proximal convoluted tubule and its attached renal corpuscle $(\times 140)$. Renal corpuscle $161 \times 136 \mu$. Tubule diameter range 50-87 $\mu .(E)$ Group of renal corpuscles, unattached except to a blood vessel and to small remnants of tubules. One small blindly-ending tubule is seen here $(\times 50)$, $(F)$ Enlargement of tubule in Fig. E clearly seen to terminate in a small diverticulum ( $\times 120)$. 
Ruch, 1940; Cox and Smellie, 1955-56). Increased tension within the renal capsule producing a 'cellophane' wrap effect has also been postulated as a possible cause (Koons and Ruch, 1940; Hughes et al., 1949; Cox and Smellie, 1955-56). On the other hand Pincoffs and Bradley (1937) reported two patients in whom hypertension subsided with removal of the tumour and kidney, only to recur with the development of metastases. In a subsequent patient Bradley and Drake (1949) found that hypertension was relieved by preoperative irradiation, and blood pressure remained normal after nephrectomy until the development of metastases, when hypertension recurred. These observations suggested the production of a humoral agent by the tumour, but these workers were unable to show pressor activity in tumour extracts (Bradley and Pincoffs, 1938; Bradley and Drake, 1949). Several cases reported showed welldifferentiated tumours with the presence of glomeruloid and tubular structures (Bradley and Drake, 1949; Hughes et al., 1949; Cox and Smellie, 1955-56; and Gooding and Raslavicius, 1965). Such marked differentiation is compatible with production of renin by the tumour. More recently Robertson et al. (1967) described a 16-year-old boy with severe hypertension associated with a small renal tumour of haemangiopericytoma type. Hypertension remitted after removal of the tumour and large quantities of renin were found in tumour extract. It appears possible that this was a renin-secreting tumour, and as such may have been responsible for the hypertension in this patient. In our patient other causes of high plasma renin levels may be suggested. The main branches of the right renal artery were stretched around the tumour and this could have produced renal ischaemia. However, the renal arteries did not appear abnormal on pathological examination, and the histological changes in the kidney resembled those seen in malignant hypertension rather than those in renal ischaemia, where the affected kidney is generally spared the ill effects of severe hypertension (Heptinstall, 1966). Another important feature in our patient was the severe electrolyte disturbance. Salt depletion is a potent cause of stimulation of the renin-angiotensin-aldosterone system (Brown et al., 1964b; Veyrat et al. 1964; Binnion et al., 1965), and marked hyponatraemia was present when the original plasma renin estimation was made. On the other hand plasma renin was considerably higher than that seen with severe salt depletion. Moreover a severe salt-wasting condition appears commonly to result from malignant hypertension rather than to be the cause of it (Barraclough, 1966).
A major difficulty in the study of these patients is the urgency of treatment. There is little time for preliminary studies of electrolyte balance before the start of anti-tumour therapy and preparation for operation, though clearly a more comprehensive study of electrolyte balance in relation to plasma renin levels would assist assessment of the role of the tumour in renin production. In particular the response to sodium loading would help determine autonomy of renin production (British Medical Journal, 1968).

The biochemical and haematological features of this child's illness rapidly reverted to normal after operation. The blood pressure returned to normal rather more slowly, suggesting that secondary hypertensive changes in the opposite kidney may also have been playing a role.

The fact that appreciable quantities of renin were found in the tumour but not in renal cortex appears to confirm that our patient had a reninsecreting tumour. Though the actual concentration was not high, because of the large size of the tumour, this would still represent a large quantity of renin. Dactinomycin, moreover, reduces tumour mass and may have inhibited renin production by the tumour as well as by the kidney. The failure to reveal any characteristically staining juxtaglomerular cells is perhaps not surprising in a tumour of this nature despite the very advanced degree of differentiation seen. The combination of a high PRC reverting to normal after operation, the presence of renin in the tumour but not in the affected kidney, and the absence of renin from the tumours of two normotensive patients, suggest a renin-secreting tumour.

Thanks are due to Drs. A. Murray Clarke and T. G. Maddison for referral of patient and permission to report this case.

\section{REFERENCES}

Barraclough, M. A. (1966). Sodium and water depletion with acute malignant hypertension. American fournal of Medicine, 40, 265.

Bartter, F. C., Pronove, P., Gill, J. R., Jr., and MacCardle, R. C. (1962). Hyperplasia of the juxtaglomerular complex with hyperaldosteronism and hypokalemic alkalosis. American Fournal of Medicine, 33, 811.

Binnion, P. F., Davis, J. O., Brown, T. C., and Olichney, M. J. (1965). Mechanisms regulating aldosterone secretion during sodium depletion. American fournal of Physiology, 208, 655.

Blair-West, J. R., Coghlan, J. P., Denton, D. A., Orchard, E., Scoggins, B. A., and Wright, R. D. (1968a). Renin-angiotensinaldosterone system and sodium balance in experimental renal hypertension. Endocrinology, 83, 1199.

- - - - - Scoggins, B. A., Wintour, M., and Wright, R. D. (1967). The renin/angiotensin-aldosterone system in sodium depletion. Medical fournal of Australia, 2, 290.

-, McCredie, D. A., and Mitchell, J. (1968b). Renin levels in nephroblastoma: report of a renin secreting tumour. Australasian Annals of Medicine, 17, 350. 
Bradley, J. E., and Drake, M. E. (1949). The effect of preoperative roentgen-ray therapy on arterial hypertension in embryoma (kidney). Fournal of Pediatrics, 35, 710.

- , and Pincoffs, M. C. (1938). The association of adeno-myosarcoma of the kidney (Wilms' tumor) with arterial hypertension. Annals of Internal Medicine, 11, 1613.

Brain, M. C., Dacie, J. V., and Hourihane, D. O'B. (1962). Microangiopathic haemolytic anaemia: the possible role of vascular lesions in pathogenesis. British fournal of Haematology, 8, 358.

British Medical fournal (1968). Editorial. Renal tumours and hypertension. 3, 327.

Brown, J. J., Davies, D. L., Lever, A. F., and Robertson, J. I. S. (1964a). Variations in plasma renin concentration in several physiological and pathological states. Canadian Medical Association fournal, 90, 201.

, , — - _ - - Bianchi, G., Imbs, J. L., Johnson, V. W., Lawrence, M., Fraser, R., and James, V. H. T. (1967). Renin and blood pressure. In Proceedings of the IIIrd International Congress of Nephrology, vol. 1, p. 226. S. Karger, Basle and New York.

- - - , and Peart, W. S. (1964b). In Aldosterone, by E. E. Baulieu and P. Robel, p. 417. Blackwell, Oxford.

Brown, T. C., Davis, J. O., Olichney, M. J., and Johnston, C. I. (1966). Relation of plasma renin to sodium balance and arterial pressure in experimental renal hypertension. Circulation Research, 18, 475.

Campbell, M. F. (1951). Clinical Pediatric Urology, p. 698. Saunders, Philadelphia and London.

Cannon, P. J., Leeming, J. M., Sommers, S. C., Winters, R. W., and Laragh, J. H. (1968). Juxtaglomerular cell hyperplasia and secondary hyperaldosteronism (Bartter's syndrome): a reevaluation of the pathophysiology. Medicine, 47, 107.

Cox, P. J. N., and Smellie, J. M. (1955-56). A case of nephroblastoma (Wilms' tumour) with severe hypertension. Gred Ormond Street fournal, No. 10, 112.

Daniel, W. E. (1939). The hypertensive factor in Wilms' tumor. Southern Medical fournal, 32, 1014.

Denys, P., Malvaux, P., van den Berghe, H., Tanghe, W., and Proesmans, W. (1967). Association d'un syndrome anatomopathologique de pseudohermaphrodisme masculin d'une tumeur de Wilms, d'une néphropathic parenchymateuse et d'un mosaïcisme XX/XY. Archives Françaises de Pédiatrie, $24,729$.

Goldblatt, H., Lynch, J., Hanzal, R. F., and Summerville, W. W. (1934). Studies on experimental hypertension. I. The production of persistent elevation of systolic blood pressure by means of renal ischaemia. Journal of Experimental Medicine, $59,347$.

Gooding, C. A., and Raslavicius, P. A. (1965). Arteriographic demonstration of perirenal hematoma and Wilms' tumor in a hypertensive child. American fournal of Roentgenology, 93, 467.

Gross, F., Brunner, H., and Ziegler, M. (196j). Renin-angiotensin system, aldosterone, and sodium balance. Recent Progress in Hormone Research, 21, 119.

Heptinstall, R. H. (1966). Pathology of the Kidney, p. 157. Little, Brown, Boston.
Howard, R. (1957). Nephroblastoma: Wilms's tumour. Medical fournal of Australia, 1, 200.

Hughes, J. G., Rosenblum, H., and Horn, L. G. (1949). Hypertension in embryoma (Wilms' tumor). Pediatrics, 3, 201.

Jagasia, K. H., Thurman, W. G., Pickett, E., and Grabstaldt, H. (1964). Bilateral Wilms' tumors in children fournal of Pediatrics, 65, 371.

Koons, K. M., and Ruch, M. K. (1940). Hypertension in a 7 year old girl with Wilms' tumor relieved by nephrectomy. fournal of the American Medical Association, 115, 1097.

Lalli, A. F., Åhström, L., Ericsson, N. O., and Rudhe, U. (1966) Nephroblastoma (Wilms's tumor): urographic diagnosis and prognosis. Radiology, 87, 495.

Lattimer, J. K., Melicow, M. M., and Uson, A. C. (1958). Wilms' tumor: a report of 71 cases. Fournal of Urology, 80, 401.

Massani, Z. M., Finkielman, S., Worcel, M., Agrest, A., and Paladini, A. C. (1966). Angiotensin blood levels in hypertensive and non-hypertensive diseases. Clinical Science, 30, 473.

Meyer, P., Ecoiffier, J., Alexandre, J. M., Devaux, C., Guize, L., Menard, J., Biron, P., and Milliez, P. (1967). Prognostic value of plasma renin activity in renovascular hypertension. Circulation, 36, 570.

Mulrow, P. J., Lytton, B., and Stansel, H. C. (1966). The role of the renin-angiotensin system in the hypertension associated with renal vascular disease. In Club International sur l'Hypertension arterielle: Première Réunion ... 1965, Paris, vol. 1, p. 296. Ed. by P. Milliez and P. Tcherdakoff. Expansion Scientifique Française, Paris.

Page, I. H. (1939). The production of persistent arterial hypertension by cellophane perinephritis. Fournal of the American Medical Association, 113, 2046.

Parkkulainen, K. V., Sirola, K., and Sulamaa, M. (1965). Results in the treatment of 'Wilms' tumour. Annals Paediatriae Fenniae, 11, 134.

Pincoffs, M. C., and Bradley, J. E. (1937). The association of adenosarcoma of the kidney (Wilms' tumor) with arterial hypertension. Transactions of the Association of American Physicians, 52, 320.

Robertson, P. W., Klidjian, A., Harding, L. K., Walters, G., Lee, M. R., and Robb-Smith, A. H. T. (1967). Hypertension due to a renin-secreting renal tumour. American fournal of Medicine, 43, 963.

Schweisguth, O., and Bamberger, J. (1965). Les metastases dans le nephroblastome de l'enfant. Archives Françaises de Pédiatrie, $22,939$.

Skinner, S. L. (1967). Improved assay methods for renin 'concentration' and 'activity' in human plasma: methods using selective denaturation of renin substrate. Circulation Research, 20, 391.

Veyrat, R. de Champlain, J., Boucher, R., and Genest, J. (1964). Measurement of human arterial renin activity in some physiological and pathological states. Canadian Medical Association Journal., 90, 215.

Correspondence to Dr. D. A. McCredie, Royal Children's Hospital, Flemington Road, Parkville. Victoria 3052, Australia. 